\title{
Partisipasi Masyarakat dalam Mengontrol dan Mengetahui Mekanisme Penggunaan Anggaran Dana Desa di Kecamatan Simalungun
}

\section{Community Participation in Controlling and Knowing The Mechasism of Village Budget Use in Kecamatan Simalungun}

\author{
Maria Ferba Editya Simanjutak \& Maslon Hutabalian \\ Program Sutudi Hukum, Fakultas Sosial dan Hukum, Universitas Quality Berastagi, Indonesia \\ Diterima: 22 Oktober 2020; Direview: 03 November 2020; Disetujui: 13 November 2020 \\ *Coresponding Email: maria.juntakk@yahoo.com, maslonhutabalian86@gmail.com
}

\begin{abstract}
Abstrak
Dana Desa adalah Dana yang bersumber dari Anggaran Pendapatan dan Belanja Negara yang diperuntukkan bagi Desa dan digunakan untuk membiayai penyelenggaraan pemerintahan, pelaksanaan pembangunan, pembinaan kemasyarakatan, dan pemberdayaan masyarakat. Pemerintahan Desa dituntut menyelenggarakan pemerintahan secara transparan dan akuntabel. Undang-undang dan Peraturan Pemerintah sudah memberikan payung hukum yang jelas sehingga BPD tidak perlu ragu dalam menjalankan fungsinya untuk melakukan pengawasan terhadap kinerja kepala desa. Penelitian ini menggunakan metode penelitian kualitatif. Pengumpulan data dilakukan melalui observasi, Wawancara mendalam dan diskusi bersama pihak terkait melalui teknik snowball. Hasil penelitian menunjukkan: Masyarakat Desa Kec. Panombeian Panei berpartisipasi dalam pengelolaan anggaran dana desa. Pengelolaan anggaran dana desa di Desa Kec.Panombeian Panei. Namun dalam pengelolaan tersebut masih kurang baik dikarnakan keputusan yang kurang bijaksana, tidak ada transparansi anggaran dan kurangnya pertanggungjawaban atas pembelanjaan anggaran dana desa itu sendiri.
\end{abstract}

Kata Kunci: Partisipasi, Mekanisme, Pengawasan, Masyarakat

\begin{abstract}
Village Funds are Funds sourced from the State Revenue and Expenditure Budget allocated for villages to be used to finance government administration, development implementation, community development, and community empowerment. Village government is required to carry out governance in a transparent and accountable manner. Laws and Government Regulations have provided a clear legal umbrella so that the $B P D$ does not need to hesitate in carrying out its function of supervising the performance of village heads. This study used qualitative research methods. Data collection was carried out through observation, in-depth interviews and discussions with related parties through snowball techniques. Data collection was carried out through observation, in-depth interviews and discussions with related parties through snowball techniques. The results showed: Village Community Kec. Panombeian Panei participates in the management of the village fund budget. Management of the village fund budget in the Village of Panombeian District Panei. How ever, the management is still inadequate due to unwise decisions, no budget transparency and a lack of accountability for the expenditure of the village fund budget itself.
\end{abstract}

Keywords: Participation, Mechanism, Supervision, Community

How to Cite: Simanjuntak, M.F.E., \& Hutabalian, M. (2020). Partisipasi Masyarakat Dalam Mengontrol Dan Mengetahui Mekanisme Penggunaan Anggaran Dana Desa Di Kecamatan Simalungun, Journal of Education, Humaniora and Social Sciences (JEHSS). 3 (3): 743-749. 


\section{PENDAHULUAN}

Undang-undang no.6 Tahun 2014 Tentang Desa, menjelaskan bahwa Desa adalah kesatuan masyarakat hukum yang memiliki batas wilayah yang berwenang untuk mengatur dan mengurus urusan pemerintahan, kepentingan masyarakat setempat berdasarkan prakarsa masyarakat, hak asal-usul, dan/atau hak tradisional yang diakui dan dihormati dalam sistem pemerintahan Negara Kesatuan Republik Indonesia (D Roza, 2017). Desa memiliki kewenangan untuk mengatur dan mengurus kepentingan masyarakatnya sendiri sesuai kondisi dan sosial budaya setempat. Konsep pengaturan Pemerintahan Desa adalah Demokratisasi yang bermakna, Penyelengaraan Pemerintahaan Desa harus mengakomodasi aspirasi masyarakat yang diartikulasi melalui Badan Permusyawaratan Desa dan Lembaga Kemasyarakatan Sebagai mitra pemerintah desa (Sulumin, 2015; Jamaluddin et al., 2018).

Peraturan Pemerintah No. 43 Tahun 2014: Dana Desa adalah Dana yang bersumber dari anggaran pendapatan dan belanja yang diperuntukan bagi desa yang ditransfer melalui anggaran pendapatan dan belanja daerah Kabupaten/Kota dipergunakan untuk penyelenggaraan pemerintahan, pelaksanaan pembagunan, pembinaan kemasyarakatan dan Pemberdayaan masyarakat. Alokasi Dana Desa Selanjutnya di singkat ADD adalah dana perimbangan yang diterima Kabupaten/Kota dalam Anggaran Pendapatan dan Belanja Daerah Kabupaten/Kota Setelah dikurangi dari Alokasi Khusus. Anggaran Pendapatan dan Belanja Desa slanjutnya di sebut APBDesa adalah rencana keuangan tahunan Pemerintah Desa.

Penyelenggaraan pemerintahan, pemerintahan desa membutuhkan sumber keuangan dan pendapatan desa. Sumber pendapatan desa dikelola melalui Anggaran Pendapatan dan Belanja Desa (APBDes). Pengelolaan keuangan desa dilakukan oleh Kepala Desa yang di tuangkan dalam Peraturan Desa tentang Anggaran Pendapatan dan Belanja Desa. Pedoman pengelolaan keuangan desa dalam pengelolaannya berpedoman pada Peraturan Menteri Dalam Negeri No.37 Tahun 2007 Tentang Pedoman Pengelolaan Keuangan Desa. Keuangan desa menurut Peraturan Pemerintah Pengganti Undang-undang No.2 Tahun 2014 tentang Pemerintah Daerah adalah semua hak dan kewajiban dalam rangka penyelenggaraan pemerintahan desa yang dapat dinilai dengan uang termasuk di dalamnya segala bentuk kekayaan yang berhubungan dengan hak dan kewajiban desa tersebut.

Kementerian Desa, Pembangunan Daerah Tertinggal, dan Transmigrasi (Kemendes PDTT) menggagas akan membuat penguatan sistem pengawasan dana desa berbasis kolaboratif. Harapan uotputnya akan menghasilkan Pedoman Pelaksanaan Pengawasan Dana Desa yang bisa dijadikan rujukan oleh Aparat Penegak Hukum (APH) dan Auditor, juga Kementerian/Lembaga. Sekretaris Jenderal Kemendes PDTT Anwar Sanusi mengatakan pengawasan dana desa menjadi isu yang sensitif. Sebab, saat ini dana desa yang digelontorkan oleh pemerintah semakin besar. Sampai akhir tahun 2018 pemerintah pusat telah menganggarkan dana untuk diberikan kepada desa melalui 19 Kementerian/Lembaga sebesar Rp 561 triliun. Ditambah lagi dengan adanya anggaran untuk dana desa yang pada tahun 2015 Rp.20,67 triliun, tahun 2016 Rp.46,98 triliun, tahun 2017 Rp.60 triliun, tahun 2018 Rp.60 triliun dan tahun 2018 Rp.70 triliun, total Rp 257,65 triliun (Widodo, 2018). Kelemahan tersebut terkait koordinasi, pemahaman teknis, kurangnya sumber daya, lemahnya kompetensi dan tidak adanya infrastruktur yang mendukung. Untuk meminimalkan penyalahgunaan dana desa perlu dibangun pola dan cara pengawasan yang kolaboratif. Hasil dari acara Temu Konsultasi Publik ini akan dibuat draft, nanti ada pertemuan selanjutnya dan pertemuan ke tiga diharapkan finishing.

Melihat dari landasan yuridis di atas maka pemerintah desa dapat pengelola segala urusan Sumber Daya Alam (SDA), Sumber Daya Manusia (SDM), administratif dan pengelolaan keuangan yang berdasarkan kebutuhan dan kepentingan masyarakatnya. Namun dalam pengelolaan sumber daya yang ada, terutama dalam pengelolaan sumberdaya manusia untuk ikut serta dalam pengelolaan keuangan desa, sehingga dalam pengelolaan keuangan desa tidak dapat mengurangi angka kemiskinan dan tidak dapat meningkatkan kesejahtraan masyarakat desa khususnya di desa Kec.Panombeian Panei. 
Jumlah desa di Kec.Panombeaian Panei 11 Desa, dan yang menjadi Sampel dalam Penelitian ini ada 5 Desa. Keuangan desa merupakan semua hak dan kewajiban dalam rangka penyelenggaraan pemerintahan desa yang dapat dinilai dengan uang, termasuk didalamnya segala bentuk kekayaan yang berhubungan dengan hak dan kewajibandesa tersebut. Keuangan desa bersumberdari pendapatan asli desa, AnggaranPendapatan dan Belanja Daerah (APBD)dan Anggaran Pendapatan dan BelanjaNegara (APBN).

Dalam pelaksanaan dan pengelolaan Keuangan Desa harus dikelola berdasarkan azas-azas transparan, akuntabel, partisipatif serta dilakukan dengan tertib dan disiplin anggaran, dan dikelola dalam masa 1 (satu) tahun anggaran yakni mulai 1 Januari sampai dengan tangga1 31 Desember dalam tahun berjalan tersebut. Begitu pula Alokasi Dana Desa yang diterima oleh tiap desa yang merupakan salah satu sumber keuangan desa dari bagian dari dana perimbangan keuangan Pusat dan daerah yang diterima oleh Pemerintah kabupaten/kota pada hekekatnya merupakan stimulan kepada desa agar mampu mengelola Alokasi Dana Desa secara efektif dan efisien. Pengelolaan Alokasi Dana Desa juga harus transparan guna mewujudkan pengembangan, kegiatan masyarakat menuju kemandirian desa.

\section{METODE PENELITIAN}

Jenis penelitian yang akan digunakan dalam penelitian ini bersifat Yuridis Empiris. Penelitian yang berbasis pada inventarisasi hukum positif, penemuan azas-azas hukum dan penemuan hukum, yang dilengkapi pengamatan operasionalisasi hukum secara empiris yakni penelitian terhadap pertanggungjawaban penggunaan dana alokasi desa dalam pemerintahan desa yang memandang gejala hukum secara murni sebagai suatu fakta sosial. Pengkajian penelitian ini menggunakan analisis kualitatif yang menghasilkan data deskriftif analitis, yaitu data yang dinyatankan oleh informan secara wawancara, serta tingkah laku yang nyata, yang diteliti dan dipelajari sebagai sesuatu yang utuh.

Dalam penelitian ini peneliti mengambil tempat yaitu di Desa Nagori Bosar. Kecamatan Panombeian Panei. Kabupaten Simalungun. Subjek penelitian ini terdiri dari Camat, Kepala Desa, Sekretaris Desa, dan beberapa masyarakat di Desa Nagori Bosar Kecamatan Panombeian Panei. Adapun fokus penelitian ini adalah Pada Partisipasi Masyarakat Dalam Mengontrol Penggunaan Anggaran Dana Desa (ADD) yang bertempat di Desa Nagori Bosar. Kecamatan Panombeian Panei. Sumber data penelitian ini terdiri dari dua macam, yaitu peristiwa, dan narasumber (informan)

\section{HASIL DAN PEMBAHASAN}

\section{Mekanisme Pertanggungjawaban Pemerintah Desa dalam Penggunaan Alokasi Dana Desa}

Tujuan dari kegiatan ini adalah untuk meningkatkan pengetahuan dan pemahaman masyarakat tentang dana desa sehingga dapat berpartisipasi dalam pengelolaan dana desa. Untuk mengetahui seberapa besar tingkat penetahuan dan pengawasan masyarakat tentang PDD, maka tim mengedarkan kuesioner kepada masyarakat di 5 desa dari 11 desa di Kecamatan Panombeian Panei, Kabupaten Simalungun.

Dari hasil kuesioner di table 1 tersebut, dapat disimpulkan bahwaPengetahuan masyarakat Sudah Cukup mengetahui terhadap dana desa sehingga berdampak pada partisipasi yang Tinggi. Dari 100 Peserta yang di mintai kosionernya, 90 \% yang mengetahui Dengan baik tentang keberadaan dana desa yang dikelola selama tiga tahun di lima desa ini. Dan hanya $60 \%$ yang terlibat dalam pelaksanaan kegiatan dana desa. Keterlibatan mereka dalam desa, ada yang sebagai anggota dari Badan Permusyawaratan Desa (BPK),dan ada pula yang terlibat dalam pengerjaan fisik seperti ketika ada program pembuatan jalan setapak. Warga yang kebetulan berprofesi sebagai pekerja bangunan/tukang, dilibatkan untuk mengerjakan jalan setapak. 
Tabel 1. Rangkuman Jawaban Responden tentang Tingkat Pengetahuan dan Partisipasi Masyarakat tentang Dana Desa di Kecamatan Panombeian Panei.

\begin{tabular}{|c|c|c|c|c|c|c|}
\hline No & Pernyataan & SS & $S$ & KS & TS & STS \\
\hline 1 & Kepatuhan Atas Perundang-Undangan & $45 \%$ & $55 \%$ & o & o & o \\
\hline 2 & Kompetensi Pemerintah Desa & $25 \%$ & $75 \%$ & o & o & o \\
\hline 3 & Partisipasi Masyarakat & $20 \%$ & $80 \%$ & o & o & o \\
\hline \multirow[t]{7}{*}{4} & Akuntabilitas Pengelolaan Dana Desa & & & & & \\
\hline & Perencanaan & $45 \%$ & $65 \%$ & o & o & o \\
\hline & Pelaksanaan & $30 \%$ & $70 \%$ & o & o & o \\
\hline & Penatausahaan & $15 \%$ & $85 \%$ & o & o & o \\
\hline & Pelaporan & $20 \%$ & $80 \%$ & o & o & o \\
\hline & Pertanggungjawaban & $15 \%$ & $85 \%$ & o & o & o \\
\hline & Jumlah Responden adalah 100 orang & & & & & \\
\hline
\end{tabular}

Mekanisme Pencairan dan penyaluran Alokasi Dana Desa ( selanjutnya di sebut ADD) mengikuti ketentuan dan tata cara Penyaluran Anggaran Pendapatan Belanja Desa (APBDes) Kabupaten Simalungun. Peraturan Bupati tentang pengelolaan ADD di jelaskan mekanisme pencairan ADD dalam Anggaran Pendapatan Belanja Desa (APBDes) di lakukan secara bertahap yang dilengkapi dengan surat rekomendasi dari camat yang menyatakan bahwa Surat Pertanggujawaban ( Selanjutnya di sebut SPJ ) tahun sebelumnya sudah dilaporkan oleh desa ke kecamatan. ADD dalam APBD kabupaten/kota dianggarkan pada bagian pemerintah desa. Pemerintah desa membuka rekening pada bank yang ditunjuk berdasarkan keputusan kepala desa. Kepala Desa mengajukan permohonan penyaluran alokasi dana desa kepada bupati c.q kepala bagian pemerintah desa sekretariat daerah kabupaten/kota melalui camat setelah dilakukan verifikasi oleh tim pendamping kecamatan. Bagian pemerintah desa pada setda kabupaten/ kota akan meneruskan berkas permohonan berikut lampirannya kepada kepala bagian keuangan setda kabupaten/ kota atau (DPKAD) Kepala Dinas Pendapatan dan kekayaan asset daerah. Kepala bagian keuangan setda atau kepala DPKAD akan menyalurkan alokasi dana desa langsung dari kas daerah ke rekening desa. Penggunaan anggaran alokasi dana desa adalah sebesar 30\% untuk belanja aparatur dan operasional pemerintah desa, sebesar $70 \%$ untuk biaya pemberdayaan masyarakat (Darmiasih, 2015)

Penggunaan ADD diserahkan kepada Pemerintah Desa dan Lembaga kemasyarakatan yang mengacu pada hasil Musyawarah Perencanaan Pembangunan Desa melalui proses perencanaan partisipatif. Proses ADD mulai dari perencanaan, pengambilan keputusan sampai dengan pengawasan serta evaluasi harus melibatkan banyak pihak. Dalam pengelolaan ADD tidak hanya melibatkan para elit desa saja (Pemerintahan Desa, Badan Permusyawaratan Desa (BPD), Pengurus desa ataupun tokoh masyarakat), tetapi harus melibatkan masyarakat lain, seperti Petani, Kaum Buruh, Perempuan, Pemuda dan lain sebagainya.

Dalam pengalokasian dana desa diperlukan fungsi Badan Permusyawaratan Desa (BPD) sebagai pengawas agar dana tersebut tersalurkan untuk kepentingan pembangunan di desa. Pengawasan yang dijalankan oleh Permusyawaratan Desa (BPD) terhadap pemakian anggaran desa dilakukan dengan melihat rencana awal program dengan realisasi pelaksanaannya. Fungsi Badan Permusyawaratan Desa (BPD) sebagai pengawas (controling). Pengawas (controling) di maksud untuk menampung dan menyalurkan aspirasi masyarakat desa. Sampai saat ini, fungsi pengawasan BPD terhadap pengelolaan ADD telah dilaksanakan semaksimal mungkin sesuai dengan tugas pokok dan fungsi dari BPD yang di tandai dengan pembangunan infrastruktur desa di Kecamatan Panombeian Panei.

\section{Pengawasan Dalam Penggunaan Alokasi Dana Desa Oleh Pemerintah Kabupaten}

Teori konsekuensi pengawasan (Fachruddin., 2004) menjelaskan bahwa pelaksanaan pengawasan terhadap pemerintah dapat ditentukan oleh beberapa teori konsekuensi pengawasan yang berpeluang dapat menjelaskan penyebab keberhasilan dan kegagalan atau efektivitas suatu

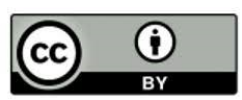


sistem pengawasan. Pertama, teori kekuatan yuridis. Kedua, teori tipe pengawasan. Dikenal dua tipe pengawasan yang paling menonjol, (a) pengawasan represif (Dunsire, 1978) diartikan sebagai pengawasan yang menggunakan cara memaksa dan mengancam dengan saksi untuk mencapai tujuannya; dan (b) pengawasan normatif (Etzioni, 1968), diartikan sebagai pengawasan yang menggunakan cara sinkronisasi pemahaman nilai-nilai dan tujuan. Ketiga, teori otoritas pengawasan, yang mencakup (a) kebsahan (legitimiteit), pengawasan dilakukan oleh badan yang diakui berwenang (Soekanto, 1988), (b) pengawasan dengan menggunakan suatu keahlian (deskundigheid) (Niemeijer, 1993), (c) pengawasan yang mendapatkan kepercayaan (geloof) (Giddings, 1993) dan (d) kesadaran hukum (rechtsbewustzjin) (Otje Salman, 1989). Keempat, teori komunikasi, yaitu proses penyampaian dan penerimaan pesan atau lambang-lambang yang mengandung arti tertentu (Soekanto, 1985) Kelima, teori publisitas, yaitu mempublikasikan masalah kepada khalayak ramai yang dapat memberi pengaruh kepada tekanan publik akibat dari opini publik (public opinion) (Ten Berge, 1991). Keenam, teori arogansi kekuasaan (Fachruddin, 2004).

Alokasi dana desa harus diawasi secara ketat dari hulu ke hilir, pengawasan sangat penting sekali dilakukan untuk meminimalkan penyelewengan dana pengembangan desa. Pengawasan terhadap ADD beserta kegiatan pelaksanaanya dilakukan secara fungsional oleh pejabat yang berwenang dan oleh masyarakat sesuai dengan perundang-undangan yang berlaku. ADD disalahgunakan, maka penyelesaiannya secara berurut, sesuai dengan ketentuan perundangan yang berlaku. Pengawasan PDD tidak terpisahkan dari struktur tugas dan kewenangan juga pertanggungjawaban sebagaimana disusun dalam struktur organisasi pelaksanaan.

Organisasi atau satuan kerja perangkat daerah (SKPD) yang memonitoring jalannya alokasi dana desa pada setiap desa di Kabupaten Simalungun dari mulai penyusunan anggaran, penatausahaan (pencairan dana ) sampai dengan pertanggung jawabannya yaitu Badan Pemberdayaan Masyarakat dan Pemerintahan Desa dan semua kecamatan yang ada di Kabupaten Simalungun. Pertanggungjawaban alokasi dana desa (ADD) terintegrasi dengan pertanggung jawaban APBDesa, sehingga bentuk pertanggung jawabannya adalah pertanggung jawaban APBDesa. Penyampaian laporan dilaksanakan melalui jalur struktural, yaitu dari tim pelaksana tingkat desa dan diketahui kepala desa ke tim pendamping tingkat kecamatan secara bertahap. Tim pendamping tingkat kecamatan membuat laporan/ rekapan dari seluruh laporan tingkat desa di wilayah dan secara bertahap melaporkannya kepada bupati cq. Tim fasilitas tingkat kabupaten/ kota. Pembiayaan dalam rangka pelaksanaan tugas pendampingan tim pendamping dibebankan kepada APBD kabupaten diluar dana Alokasi Dana Desa (ADD). Pemerintah dapat melakukan pendampingan kepada masyarakat desa secara berkelanjutan, termasuk dalam penyediaan Sumber Daya Manusia (SDM) dan manajemen. Ada tujuh tugas pendamping: (1) mendampingi desa dalam perencanaan, pelaksanaan, dan pemantauan terhadap pembangunan desa dan pemberdayaan masyarakat desa; (2) mendampingi desa dalam pengelolaan pelayanan sosial dasar, pengembangan ekonomi desa, pendayagunaan sumber daya alam dan teknologi tepat guna, pembangunan sarana dan prasarana desa, dan pemberdayaan masyarakat desa; (3) meningkatkan kapasitas pemerintahan desa dan lembaga kemasyarakatan desa; (4) melakukan pengorganisasian kelompok-kelompok masyarakat desa; (5) melakukan peningkatan kapasitas kader pemberdayaan masyarakat desa dan mendorong terciptanya kader-kader pembangunan masyarakat yang baru; (6) mendampingi desa dalam pembangunan kawasan perdesaan yang partisipatif; (7) melakukan koordinasi pendampingan di tingkat kecamatan dan memfasilitasi laporan pelaksanaan pendampingan oleh camat kepada bupati/walikota (Adnan, 2016) .

Sistem pengawasan yang dilakukan oleh Badan Perwakilan Desa, mempunyai peran yang strategis dalam ikut mengawal penggunaan dana desa tersebut agar tidak disalahgunakan sesuai dengan ketentuan pasal 48 dan 51 Peraturan Pemerintah No 433 tahun 2014 tentang desa dimana pengawasan penggunaan anggaran harus dilakukan akuntabel, transparan, dan di ketahui oleh masyarakat. Dalam pelaksanaannya, Kepala desa dibantu oleh Pelaksana Teknis Pengelolaan Keuangan Desa (PTPKD) yang merupakan perangkat desa yang ditunjk kepala desa, PTPKD merupakan unsur perangkat desa yang membantu Kepala desa untuk melaksanakan pengelolaan 
keuangan desa. Bendahara di jabat oleh staf pada Urusan Keuangan. Bendahara mempunyai tugas menerima, menyimpan, meyetorkan tau membayar, menatausahakan, dan mempertanggungjawabkan penerimaan pendapatan desa dan pengeluaran pendapatan desa dalam rangka pelaksanaan APBDesa.

Laporan berkala dan laporan akhir Penggunaan ADD harus di buat sesuai dengan Peraturan Bupati. Penyampaian laporan atas realisasi penggunaan dana yang dibiayai oleh ADD dilaksanakan secara berjenjang oleh Kepala Desa Kepada Tim Pendamping Kecamatan kemudian Tim Pendamping Kecamatan membuat Laporan Tingkat Desa. Laporan ini selanjutnya dilaporkan kepada Bupati melalui BPMPDK Kabupaten Simalungun sebagai dasar untuk melakukan penyaluran dana. Dalam proses penyampaian laporan penggunaan Alokasi Dana Desa (ADD), Kepala Desa yang bersangkutan dituntut untuk menyampaikan laporan tepat waktu. Apabila laporan tersebut tidak tepat waktu atau terlambat dilaporkan maka Bupati berhak untuk menunda pencairan dana untuk tahap selanjutnya dan pengurangan dana yang bersumber dari APBD Kabupaten untuk tahun berikutnya sesuai dengan penelian Tim pengendali Kabupaten dan tim fasilitasi Kecamatan yang di bentuk dengan Keputusan Bupati.

\section{SIMPULAN}

Pengawasan terhadap Alokasi Dana Desa beserta kegiatan pelaksanaanya dilakukan secara fungsional oleh pejabat yang berwenang dan oleh masyarakat sesuai dengan Peraturan Perundnag-undangan yang berlaku. Hasil Penelitian menunjukkan bahwa struktur organisasi pelaksanaan alokasi dana desa telah dibentuk dengan baik sehingga memberikan garis kewenangan dan tugas serta arah pertanggungjawaban antar fungsi yang jelas. Pengawasan penggunaan Alokasi Dana Desa oleh pemerintah Kabupaten dilakukan terhadap jalannya pemerintahan dan pembangunan agar dalam pelaksanaannya tidak menyimpang dari rencana yang telah ditetapkan dan aturan yang berlaku berdasarkan terhadap pelaksaan fisik maupun pengelolaan keuangan.

\section{UCAPAN TERIMAKASIH (Optional)}

Terima kasih peulisan ucapkan kepada Direktorat Riset dan Pengabdian Masyarakat (DRPM) kementrianriset dan tekhnologi dengan Kontrak No.256/LL1/PG/2020. Terima Kasih Kepada Camat dan Kepala-kepala desa di Kec. Panombeian Panei, Kab.Simalungun yang telah berkontribusi membantu dalam pelaksanaan penelitian ini.

\section{DAFTAR PUSTAKA}

Adhan. A, (2016), Pengawasan Alokasi Dana Dasa Dalam Pemerintahan Desa, Fak.Hukum Univ.Islam Bandung, Al'Adl, vol VIII No.2. https://media.neliti.com/media/publications/225055-pengawasanalokasi-dana-desa-dalam-pemer-a46888e9.pdf

D. Roz, L Arliman, (2017), Peran Badan Permusyawaratan Desa di Dalam Pembangunan Desa dan Pengawasan Keungan Desa, Padjadjaran Journal of Law. http://jurnal.unpad.ac.id/pjih/article/view/13854

Darmiasih, N.K, (2015), Analisis Mekanisme Penyaluran Alokasi Dana Desa (ADD) pada Pemerintah Desa ( studi Kasus di Desa Tri Buana, Kec. Sidemen, Kabupaten Karengasem, e-Journal S1 Universitas $\begin{array}{llll}\text { Pendidikan } & \text { Ganesha } & \text { (vol, } & \text { No.4), }\end{array}$ https://ejournal.undiksha.ac.id/index.php/S1ak/article/view/5027/3792

Dunsire, A, (1978), Control in a Bureaucracy, New York.

Etzioni, A, (1968), The active society; a theory of cietal and political prosess, London

Fachruddin. I, (2004), Pengawasaan Peradilan Administrasi Terhadap Tindakan Pemerintah, Alumni, Bandung

Gidding.P, (1993), Controlling dministrative Action in the United Kingdom: The Role of Ombudsman System and The Court ompard, Rev.of Administrative Sciences. 
Jamaluddin, Y. Sumaryana, A. Rusli, B. \& Buchari, R.A. (2018). Analisis Dampak Pengelolaan dan Penggunaan Dana Desa terhadap Pembangunan Daerah. JPPUMA: JPPUMA: Jurnal Ilmu Pemerintahan dan Sosial Politik UMA (Journal of Governance and Political UMA), 6 (1): 14-24.

Sulaimin, H.H. (2015), Pertanggungjawaban Penggunaan Alokasi dana Desa Pada Pemerintahan Desa di Kabupaten Donggala, Journal http://jurnal.untad.ac.id/jurnal/index.php/Katalogis/article/view/4246

Niemeijer, E \&Timmer, J.S., (1993), Het ABC van e Nationale ombusdman; arbiter, bewaker en consulent, Bestuurskunde

Salman. O.R, (1989), Beberapa Aspek Sosiologi Hukum, Alumni, Bandung

Soekanto. S, (1985), efektivitas Hukum dan Peranan Sanksi, Ramadja Karya, Bandung

Soekanto. S, (1988), Pokok-pokok Sosiologi Hukum, Rajawali Pers, Jakarta

Ten Berge, J.B.J.M, (1991), De beketenis van de Nationale ombudsman voor het bestuursrecht, in : de Nationale ombudsman, VAR-reeks 106, Alphen aan den rijn.

Peraturan Menteri Dalam Negeri No.37 Tahun 2007 Tentang Pedoman Pengelolaan Keuangan Desa

Peraturan Pemerintah Pengganti Undang-undang No.2 Tahun 2014 Tentang Pemerintah Daerah

UU No 6 Tahun 2014 Tentang Desa 